\title{
OPTIMASI TEKNIK WESTERN BLOT UNTUK DETEKSI EKSPRESI PROTEIN TANAMAN PADI (Oryza sativa L.)
}

\section{Optimization of Western Blot Technique for Protein Expression of Rice Plant (Oryza sativa L.)}

\author{
Susianti ${ }^{1,3}$, Edi Sukmana ${ }^{2}$, Ronny Lesmana ${ }^{1,2}$, Unang Supratman ${ }^{1,3}$ \\ ${ }^{1}$ Laboratorium Sentral Universitas Padjadjaran, Jatinangor \\ 2Departemen IImu Kedokteran Dasar, Fakultas Kedokteran, Universitas Padjadjaran, Jatinangor \\ ${ }^{3}$ Departemen Kimia, Fakultas Matematika dan Ilmu Pengetahuan Alam, Universitas Padjadjaran, Jatinangor \\ *Email: susianti@unpad.ac.id
}

\begin{abstract}
Western blot (WB) technique has been widely used for analyzing protein expression and for identifying specific proteins derived from animals, plants, and microorganisms. During the use of WB, especially in agricultural studies, some difficulties are encountered such as unclear or unspecific protein bands, the presence of bubbles, and the absence of protein bands on membrane. This study aims to determine the WB conditions appropriate for the protein expression of rice plants (Oryza sativa L.). Protein from rice plant was extracted and the obtained protein lysate was then used for proteomic analysis using WB with $\beta$-actin antibody. Our experiment showed that some optimized parameters like blocking buffers, the concentration of primary antibody and the ratio of secondary antibody determined the clarity of the results. $\beta$-actin was used as internal control that measured the success of the WB technique. Results showed that lysis process was important in determining good WB results in addition to the optimal blocking solution using a BSA of $0.2 \%$, a primary antibody concentration of $1 \mu \mathrm{g} \mathrm{mL} \mathrm{L}^{-1}$, and a secondary antibody of 1:10,000. Optimizing techniques during extraction, incubation, and documentation facilitated good WB results.
\end{abstract}

Keywords: $\beta$-actin, optimization, protein, rice plant, western blot

\section{ABSTRAK}

Teknik western blot (WB) telah banyak digunakan untuk analisis ekspresi protein dan mengidentifikasi protein spesifik dari hewan, tumbuhan dan mikroorganisme. Dalam implementasi teknik WB, khususnya studi dalam bidang pertanian, beberapa kesulitan ditemui seperti pita protein tidak jelas, tidak spesifik, adanya gelembung, hingga tidak munculnya pita protein pada membran. Penelitian ini bertujuan untuk mengetahui kondisi WB yang tepat untuk deteksi protein tanaman padi (Oryza sativa L.). Protein tanaman padi diekstraksi, kemudian lisat protein yang didapat dianalisis dengan metode WB menggunakan antibody $\beta$-actin. Penelitian kami menunjukkan bahwa beberapa parameter yang dioptimasi seperti larutan blocking, konsentrasi antibodi primer dan rasio antibodi sekunder akan menentukan hasil yang jelas. $\beta$ actin digunakan sebagai kontrol internal yang menjadi tolok ukur keberhasilan teknik WB. Hasil menunjukkan bahwa proses lisis menjadi hal penting dalam menentukan hasil WB yang baik disamping larutan blocking yang optimal menggunakan BSA $0,2 \%$, konsentrasi antibodi primer $1 \mu \mathrm{g} \mathrm{mL}^{-1}$ dan antibodi sekunder 1:10.000. Mengoptimalkan teknik selama ekstraksi, inkubasi dan dokumentasi membantu mendapatkan hasil WB yang baik.

Kata Kunci: $\beta$-actin, optimasi, protein, tanaman padi, western blot 


\section{PENDAHULUAN}

Padi (Oryza sativa L.) adalah salah satu tanaman yang menjadi sumber makanan pokok jutaan orang pada hampir separuh populasi dunia khususnya di benua Asia (Li et al. 2011, Mahmood dan Yang 2012, Esa et al. 2013, Wu et al. 2014). Sebagai bahan konsumsi pangan terpenting, yang jumlahnya terus bertambah seiring dengan pertambahan jumlah penduduk, peningkatan kualitas padi menjadi tantangan tersendiri bagi para peneliti (Zhang et al. 2017b). Terlebih padi juga merupakan model tanaman monokotil yang banyak digunakan baik studi genomik dan proteomik. Menurut Gulcicek et al. (2005), dengan berkembangnya teknologi dalam beberapa tahun terakhir, banyak studi proteomik telah dilakukan baik untuk identifikasi, karakterisasi maupun analisis tingkat ekspresi protein dari sel atau jaringan hewan dan tanaman. Berbagai metode yang dapat digunakan dalam analisis protein diantaranya adalah kolorimetri, kromatografi cair, elektroforesis 1-dimensi dan 2-dimensi, serta western blot (Esteves et al. 2019).

Western blot (WB) adalah salah satu teknik biologi molekuler untuk analisis ekspresi protein semi-kuantitatif dari berbagai macam bahan uji baik dari sel maupun jaringan dengan prinsip kerjanya berdasarkan pengikatan antigen-antibodi (Gilda dan Gomes 2013, Nie et al. 2017). Tahapan teknik WB dimulai dari preparasi sampel (ekstraksi dan pemurnian protein, pengukuran konsentrasi serta banyaknya jumlah protein yang akan digunakan), pemisahan protein menggunakan elektroforesis gel poliakrilamida, transfer protein dari gel ke membran nitroselulosa atau PVDF (polyvinylidene difluoride), membran blocking, inkubasi antibodi primer dan sekunder, deteksi protein target, perhitungan intensitas pita protein menggunakan software digital densitometri, dan normalisasi data menggunakan kontrol internal protein (Mishra et al. 2017). Selain analisis ekspresi protein, teknik WB digunakan untuk mendeteksi interaksi struktur protein-protein secara in vitro, yang dinamakan "far-western blot" (Cima-Cabal et al. 2019). Feckova et al. (2016) melakukan penelitian dengan menggunakan metode Far-WB untuk analisis interaksi di antara
Erythropoietin (Epo) dengan Erythropoietin receptor (EpoR) pada sel kanker ovarium manusia A2780. Li et al. (2015) mengidentifikasi ikatan protein antara laminin dan fibronectin menggunakan FarWB. Hingga saat ini, WB juga digunakan untuk diagnosis berbagai penyakit dan infeksi. Banyak penelitian dasar maupun klinis dilakukan menggunakan teknik WB (Huang et al. 2019). Walentowicz-Sadlecka et al. (2018) menganalisis ekspresi protein Human Leukocyte Antigen-G (HLA-G) pada penderita kanker endometrial. Teknik WB juga menjadi salah satu metode yang sensitif dan selektif untuk deteksi parasit Echinococcus multilocularis pada famili Canidae (Schurer et al. 2019). Villafanez et al. (2019) melakukan optimasi teknik WB untuk identifikasi regulator PostTranslational Modifications (PTM). Seiring dengan kemajuan teknologi, mulai dikembangkan beberapa metode alternatif untuk meningkatkan sensitivitas dan reproduktivitas teknik WB di antaranya metode WB-resolusi satu sinyal, Far-WB, blotting difusi, WB-mikrofluida otomatis, WBelektroforesis kapiler dan elektroforesis mikrochip (Mishra et al. 2017).

Teknik WB merupakan metode yang pengerjaannya sederhana, spesifik dan tepat ( $\mathrm{Li}$ et al. 2011). Namun demikian, dalam implementasi teknik WB untuk penelitian tertentu khususnya studi dalam bidang pertanian, beberapa kesulitan teknik ditemui seperti pita protein tidak jelas, tidak spesifik, adanya gelembung, hingga tidak munculnya pita protein pada membran (Mahmood dan Yang 2012). Oleh karena itu, memahami proses optimasi kondisi WB untuk mendapatkan hasil WB yang terbaik menjadi sangat penting, karena kondisi optimal setiap pengerjaan WB berbeda-beda, mulai dari persiapan dan penanganan sampel, hingga pemilihan dan validasi antibodi yang digunakan untuk deteksi protein (AlegriaSchaffer et al. 2009, Huang et al. 2019).

Penelitian ini bertujuan untuk mengetahui kondisi WB yang tepat untuk deteksi protein tanaman padi (Oryza sativa L.). Parameter WB yang dioptimasi meliputi larutan blocking yang digunakan, konsentrasi antibodi primer dan antibodi sekunder. $\beta$-actin digunakan sebagai kontrol internal protein yang menjadi tolok ukur keberhasilan teknik WB. 


\section{BAHAN DAN METODE}

\section{Waktu dan lokasi penelitian}

Penelitian ini dilakukan di Laboratorium Sentral Universitas Padjadjaran, Jatinangor, Sumedang pada tanggal 6 Mei-24 November 2018.

\section{Bahan}

Daun tanaman padi (Oryza sativa L.) berumur 30 hari (Gambar 1) diperoleh dari lahan persawahan di Cibiuk Garut (705'10.0"S 107²56'49.9"E), dibersihkan dan dipotong menjadi ukuran yang lebih kecil sebelum digunakan (Wang et al. 2008).

Bahan-bahan lain yang digunakan meliputi antibodi primer $\beta$-actin, antibodi sekunder yang berkesesuaian, 2merkaptoetanol (Sigma), 2-propanol (Merck), amonium asetat (Merck), amonium persulfat (APS) (Merck), asam asetat glasial (Merck), asam klorida (Merck), asam

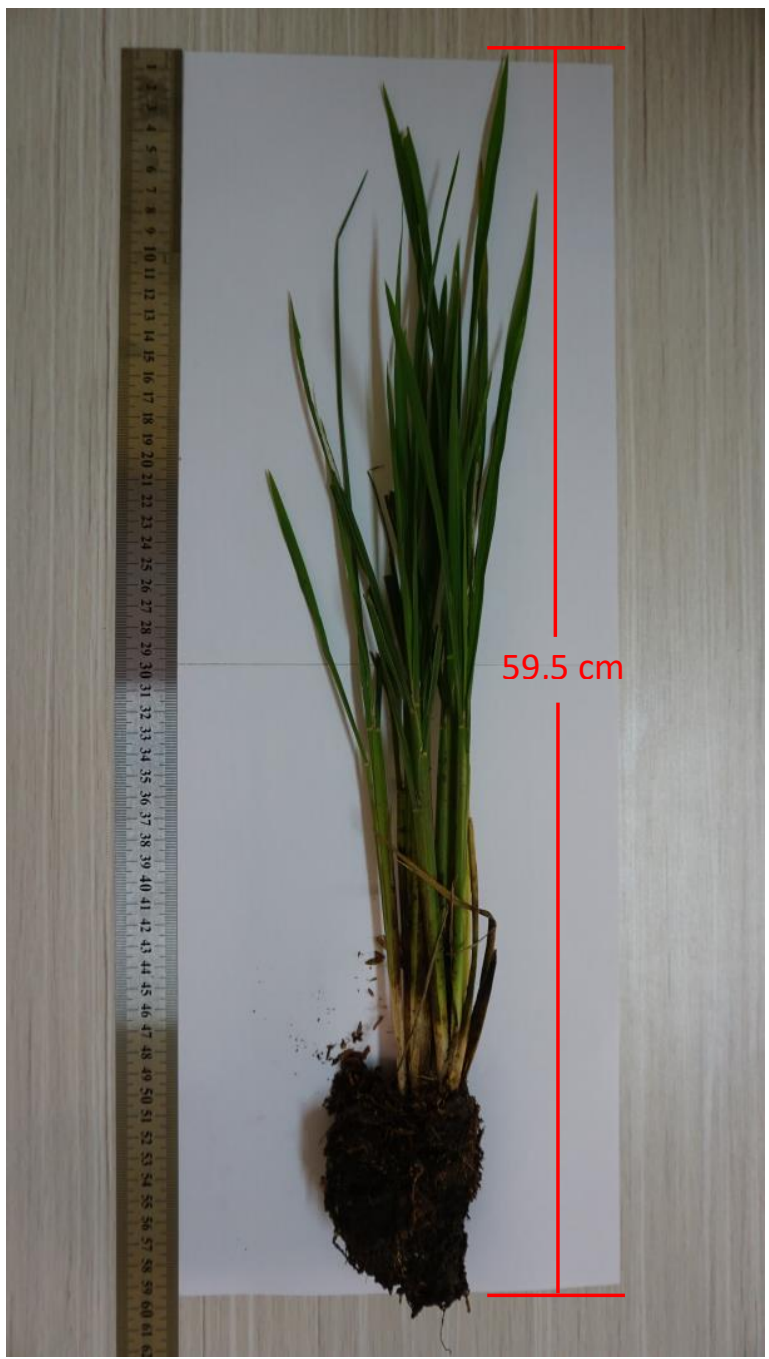

Gambar 1. Sampel tanaman padi etilenadiaminatetraasetat (EDTA) (Merck), aseton (Merck), bovine serum albumin (BSA) (Sigma), dithiothreitol (DTT) (Promega), Folin-Ciocalteu (Merck), glisin (Merck), kalium klorida (Merck), protein ladder (Thermo Scientific 26612), larutan dapar ekstraksi, larutan dapar lisis, Iarutan dapar pengendap, larutan dapar sampel, Mili-Q (Sartorius), metanol (Merck), natrium hidroksida (Merck), natrium klorida (Merck), nitrogen cair, polivinilpirolidon (PVP) (Wako), phosphate buffer saline (PBS) $\mathrm{pH} \quad 7,4$ (Gibco), poliakrilamida $40 \%$ (Biorad), resolving buffer, running buffer, SilverQuest ${ }^{\mathrm{TM}}$ LC6070 silver staining kit (Invitrogen, Thermo), sodium dedocyl sulfate (SDS) $10 \%$ (1st base), stacking buffer, substrat chemiluminescence (GE Healthcare), sukrosa (Merck), susu skim (Tropicana Slim), tetramethylethylenediamine

(TEMED) (Invitrogen), transfer buffer, triton X-100 (Invitrogen), tris-base (Promega), tween 20 (Merck), urea (Merck).

\section{Ekstraksi protein}

Ekstraksi protein daun tanaman padi dilakukan dengan metode Lin dan Wang (2014) yang telah dimodifikasi dengan penghilangan bahan kimia fenol dalam dapar ekstraksi, penghilangan tahapan pencucian pelet menggunakan aseton dan pengeringan vakum (Tabel 1). Sebanyak 1,5 g daun tanaman padi dihaluskan hingga menjadi serbuk dengan mortar dan alu menggunakan nitrogen cair. Ekstraksi dilakukan pada suhu $4^{\circ} \mathrm{C}$. Selanjutnya ditambahkan $5 \mathrm{~mL}$ larutan dapar ekstraksi, dan $0,5 \mathrm{~g}$ polivinilpirolidon sambil ditumbuk, dan ditambahkan kembali $5 \mathrm{~mL}$ larutan dapar ekstraksi, ditumbuk hingga berbuih. Lalu protease inhibitor ditambahkan sebanyak $25 \mu \mathrm{L}$ dan larutan dapar ekstraksi sebanyak $5 \mathrm{~mL}$. Campuran ditumbuk hingga berbuih. Setelah itu, campuran dipindahkan ke dalam tabung $1,5 \mathrm{~mL}$ dan disentrifugasi dengan kecepatan 15.000 rpm pada suhu $4^{\circ} \mathrm{C}$ selama 20 menit. Filtrat disaring dan dipindahkan ke dalam tabung baru $1,5 \mathrm{~mL}$, ditambahkan dapar pengendap ke dalam filtrat dengan perbandingan 3:1 dan diinkubasi pada $-20^{\circ} \mathrm{C}$ selama 4 jam. Campuran disentrifugasi selama 20 menit, $15.000 \mathrm{rpm} 4^{\circ} \mathrm{C}$. Pelet dicuci sebanyak 2 kali dengan $1,8 \mathrm{~mL}$ larutan dapar pengendap. Pelet diresuspensi menggunakan larutan 
Tabel 1. Tahapan optimasi teknik western blot

\begin{tabular}{lcc}
\hline Tahapan Teknik Western Blot & Referensi Jurnal & Optimasi \\
\hline Ekstraksi protein & $\begin{array}{c}\text { Menggunakan fenol, aseton } \\
\text { dan pengeringan vakum } \\
\text { metode Lin dan Wang (2014) }\end{array}$ & $\begin{array}{c}\text { Tidak menggunakan fenol, } \\
\text { aseton dan pengeringan } \\
\text { vakum }\end{array}$ \\
$\begin{array}{l}\text { Elektroforesis gel poliakrilamida } \\
\text { Pewarnaan protein }\end{array}$ & - & Menggunakan gel tris-glisin \\
Transfer protein & - & Pewarnaan perak (silver stain) \\
Blocking & - & Menggunakan susu skim $0,2 \%$ atau BSA $0,2 \%$ \\
Inkubasi antibodi primer & - & Konsentrasi $1 \mu \mathrm{mL} \mathrm{m} \mathrm{mL}^{-1}$ \\
Inkubasi antibodi sekunder & - & Konsentrasi $1: 10.000$ \\
Deteksi protein target & - & Chemiluminescence
\end{tabular}

dapar lisis secukupnya dan ditambahkan protease inhibitor 1:1.000. Lisat protein dapat disimpan pada suhu $-80^{\circ} \mathrm{C}$ sebelum digunakan untuk analisis selanjutnya.

\section{Kuantifikasi protein}

Untuk mengetahui jumlah protein dalam tanaman padi dilakukan kuantifikasi menggunakan metode Lowry yang telah dimodifikasi. Lisat protein sebanyak $0,25 \mathrm{~mL}$ dimasukkan ke dalam tabung reaksi, ditambahkan 2,5 $\mathrm{mL}$ reagen Lowry, dihomogenkan menggunakan vortex kemudian diinkubasi selama 10 menit pada suhu $50^{\circ} \mathrm{C}$. Setelah itu, campuran ditambahkan reagen Folin-Ciocalteu 1:1 sebanyak $0,5 \mathrm{~mL}$, diinkubasi kembali selama 10 menit pada suhu $50^{\circ} \mathrm{C}$. Absorbansi sampel diukur menggunakan spektrofotometer pada panjang gelombang $650 \mathrm{~nm}$. Konsentrasi sampel dihitung dengan menggunakan kurva standar bovine serum albumin (BSA).

\section{Elektroforesis gel poliakrilamida}

Pemisahan protein daun tanaman padi dilakukan menggunakan elektroforesis poliakrilamida berdasarkan metode Lesmana dan Hanna (2017). Lisat protein ditambahkan dapar sampel dengan perbandingan 1:1, didenaturasi pada suhu $95^{\circ} \mathrm{C}$. Sampel dimasukkan ke dalam tujuh sumur gel poliakrilamida, sebanyak $20 \mu \mathrm{L}$ tiap sumur. Voltase diatur pada tegangan $80-100 \mathrm{~V}$ selama 90 menit. Pewarnaan gel hasil elektroforesis dilakukan dengan metode pewarnaan perak menggunakan SilverQuest ${ }^{\mathrm{TM}}$ LC6070 silver staining kit (Invitrogen, Thermo).

\section{Transfer protein}

Gel hasil elektroforesis poliakrilamida ditransfer pada membran menggunakan metode transfer basah kemudian alat transfer dinyalakan selama 30 menit, $200 \mathrm{~mA}$. Setelah itu, hasil transfer dapat dicek dengan menggunakan pewarnaan Ponceau S.

\section{Deteksi protein dengan antibodi}

Membran dicuci menggunakan phosphate buffer saline-tween 20 (PBST) $0,1 \% 3 \times 5$ menit. Proses blocking membran dengan menggunakan susu skim $0,2 \%$ atau BSA $0,2 \%$ pada suhu ruangan selama 60 menit. Setelah selesai, membran dicuci dengan PBST $0,1 \%$ selama 5 menit dan dilakukan berulang sebanyak 3 kali. Selanjutnya larutan antibodi primer $\beta$-actin dengan konsentrasi $1 \mu \mathrm{g} \mathrm{m} \mathrm{m}^{-1}$ ditambahkan ke dalam membran, kemudian diinkubasi $4^{\circ} \mathrm{C}$ semalam. Setelah itu, membran dicuci dengan menggunakan PBST 0,1\% $3 \times 5$ menit. Kemudian langkah selanjutnya penambahan larutan antibodi sekunder dengan konsentrasi 1:10.000, kemudian diinkubasi pada suhu ruangan selama 1,5 jam. Membran dicuci kembali dengan menggunakan PBST $0,1 \% 3 \times 5$ menit dan substrat chemiluminescence ditambahkan ke dalam membran, diinkubasi selama 5 menit lalu dideteksi protein $\beta$-actin dengan menggunakan alat C-Digit LICOR.

\section{HASIL DAN PEMBAHASAN}

\section{Ekstraksi protein}

Hasil ekstrasi protein daun tanaman padi didapatkan lisat protein yang jernih (Gambar 2). Ekstraksi protein merupakan 
tahapan paling penting dalam teknik WB, terutama pada sampel tanaman (Vilhena et al. 2015), dikarenakan jaringan tanaman memiliki jumlah protease yang tinggi dan kandungan metabolit sekunder yang biasanya menjadi pengganggu pada proses ekstraksi karena sulit untuk dihancurkan (Wang et al. 2008), sehingga untuk mendapatkan hasil lisat protein yang tinggi bergantung pada pemilihan protokol ekstraksi protein dan setiap tahapan dari ekstraksi protein tersebut (Niu et al. 2018).

Ekstraksi protein dilakukan menggunakan metode Lin dan Wang (2014) yang telah dimodifikasi dengan penghilangan bahan kimia fenol dalam larutan dapar ekstraksi, penghilangan tahapan pencucian pelet menggunakan aseton dan pengeringan vakum. Fenol digunakan dalam larutan dapar ekstraksi sebagai pengikat protein dan untuk mengurangi degradasi protein. Metode ekstraksi protein menggunakan fenol memiliki aktivitas yang baik untuk mengurangi interaksi molekuler antara protein dan bahan lain, namun fenol memiliki sedikit kecenderungan untuk melarutkan asam nukleat dan polisakarida (Chatterjee et al. 2012). Selain itu, fenol termasuk ke dalam bahan berbahaya yang bersifat racun karena sulit diuraikan oleh organisme sehingga dalam penelitian ini larutan dapar ekstraksi dibuat tanpa penambahan fenol, sedangkan penghilangan tahapan pencucian pelet menggunakan aseton dan pengeringan vakum bertujuan untuk mencegah hilangnya protein yang lebih banyak pada saat ekstraksi dan efisiensi waktu ekstraksi protein.

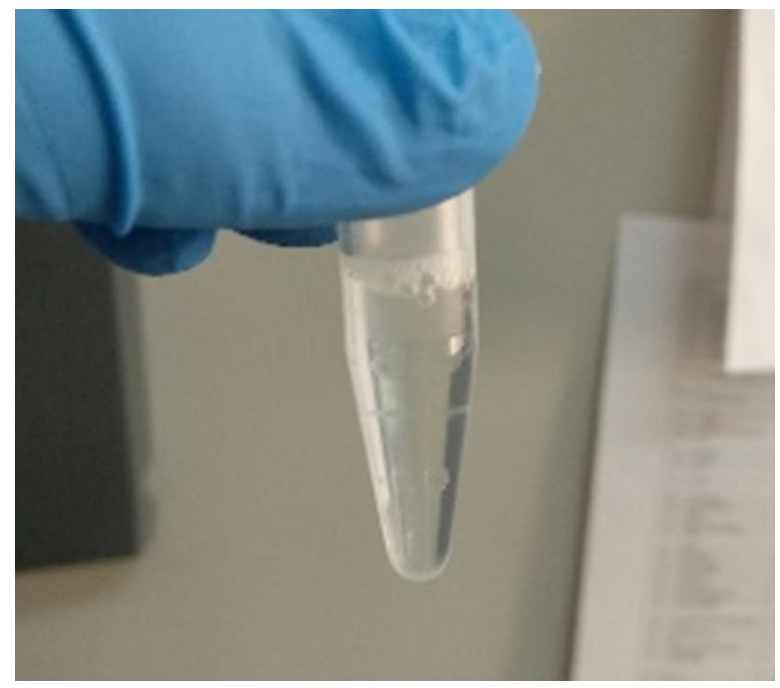

Gambar 2. Lisat protein daun tanaman padi
Pencucian dengan aseton biasanya dilakukan untuk membantu menghilangkan sisa garam natrium asetat dari larutan dapar pengendap yang digunakan sebelumnya, dan juga untuk mengurangi terjadinya degradasi protein (Rodrigues et al. 2012).

\section{Kuantifikasi protein}

Jumlah lisat protein daun tanaman padi diukur menggunakan metode Lowry. Hasil kuantifikasi protein dari lisat daun tanaman padi yang didapat sebesar $239,5 \mu \mathrm{g} \mathrm{LL}^{-1}$. Menurut Kurien dan Scofield (2015), pengukuran protein metode Lowry berdasarkan pada dua reaksi. Pertama, pembentukan kompleks ion tembaga dengan ikatan amida membentuk tembaga tereduksi (disebut juga kromofor biuret) dan biasanya stabil dengan penambahan natrium-kalium tartrat. Reaksi kedua yaitu reduksi reagen Folin-Ciocalteu oleh kompleks tembagaamida beserta residu tirosin dan triptofan. Warna biru yang terbentuk dapat diukur absorbansinya dengan spektrofotometer. BSA dijadikan sebagai standar untuk perhitungan konsentrasi protein.

\section{Elektroforesis gel poliakrilamida}

Untuk melihat pemisahan protein daun tanaman padi berdasarkan berat molekulnya, digunakan teknik elektroforesis gel poliakrilamida (Bass et al. 2017). Lisat protein ditambahkan larutan dapar sampel lalu didenaturasi pada suhu $95^{\circ} \mathrm{C}$ selama 5 menit. Dapar sampel terdiri dari gliserol yang berfungsi untuk meningkatkan densitas sampel sehingga sampel dengan mudah

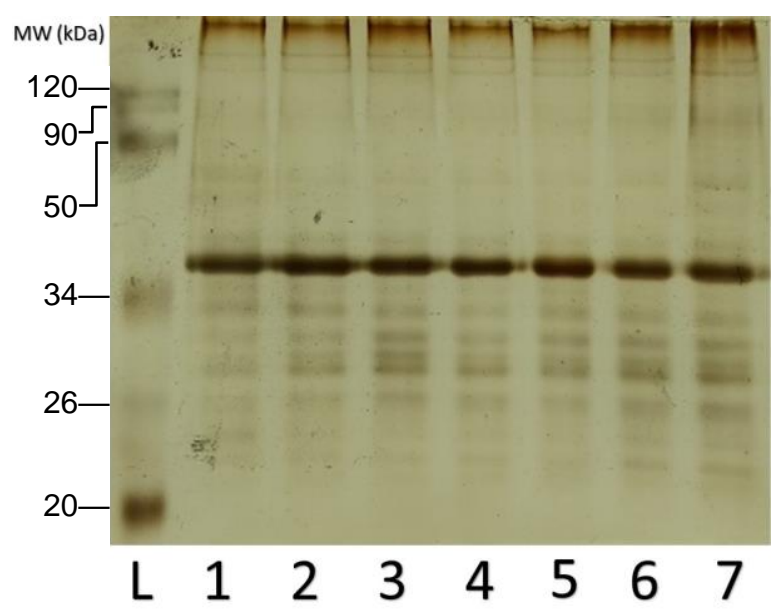

Gambar 3. Hasil pewarnaan perak daun tanaman padi (L: Ladder protein, 1-7: Lisat protein daun tanaman padi) 
turun ke dasar sumur gel, bromophenol blue sebagai tracking dye, dan 2-merkaptoetanol yang berfungsi untuk mereduksi ikatan disulfida menjadi protein yang bermuatan sehingga pada saat elektroforesis berlangsung, sampel akan bermigrasi melalui gel dari katoda (-) menuju anoda (+) (Mahmood dan Yang 2012).

\section{Pewarnaan gel (pewarnaan perak)}

Gel hasil elektroforesis dilakukan pewarnaan menggunakan metode pewarnaan perak untuk melihat pemisahan protein. Hasil pewarnaan pada Gambar 3 menunjukkan bahwa protein tanaman padi terseparasi dengan baik sesuai dengan ukuran berat molekulnya. Pada pewarnaan perak, ion perak yang berasal dari reagen perak nitrat berikatan dengan rantai samping yang bermuatan negatif dari protein sehingga dihasilkan warna coklat kehitaman pada gel poliakrilamida. Pewarnaan gel menggunakan metode pewarnaan perak 30-100 kali lebih sensitif dari metode coomassie blue (Zhao et al. 2012).

\section{Transfer protein}

Setelah proses elektroforesis poliakrilamida selesai, dilanjutkan proses transfer protein dari gel ke membran (blotting) dengan membuat "sandwich": Katoda(-) sponge pad (kasa) - kertas saring - gel membran - kertas saring - sponge pad (kasa) - Anoda(+). Harus dipastikan posisi penempatan gel dan membran tidak terbalik serta tidak ada gelembung yang

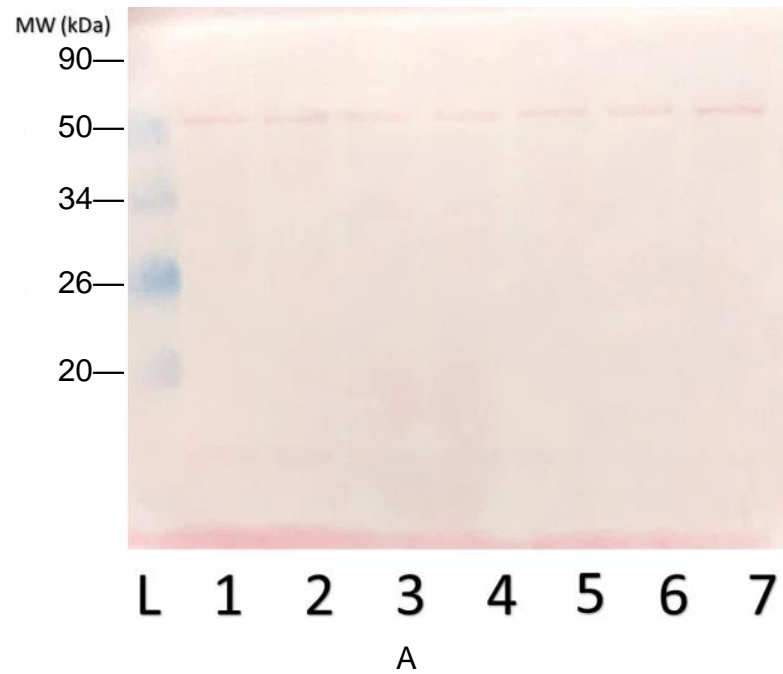

terperangkap di antara gel dan membran yang dapat mengakibatkan hasil transfer tidak optimal (Mahmood dan Yang 2012). Metode transfer yang digunakan yaitu transfer basah, dimana selama proses transfer, larutan dapar digunakan untuk meningkatkan permeabilitas gel poliakrilamida, sehingga membantu proses transfer protein menjadi lebih cepat (Gibbons 2014).

Membran yang digunakan dalam proses transfer protein yaitu nitroselulosa. Biasanya membran nitroselulosa digunakan untuk protein yang memiliki afinitas tinggi (Mahmood dan Yang 2012). Tanaman padi diketahui mengandung protein HKT (Highaffinity $K^{+}$Transporter) yang berperan dalam mempertahankan homeostatis $\mathrm{Na}^{+} / \mathrm{K}^{+}$pada tanaman (Ariyarathna et al. 2016, Zhang et al. 2017a).

Untuk melihat keberhasilan proses transfer protein, dilakukan pewarnaan membran menggunakan Ponceau S (Bass et al. 2017). Ponceau S merupakan metode pewarnaan negatif dimana akan berikatan dengan gugus amino yang bermuatan positif. Protein yang ditransfer (> 200 ng) akan muncul sebagai pita merah jambu. Hasil pewarnaan Ponceau dilakukan pada 2 membran, dan didapatkan hasil pita merah jambu seperti terlihat pada Gambar 4 yang menandakan bahwa proses transfer protein dari gel ke membran berhasil dengan baik. Kelebihan dari pewarnaan Ponceau $S$ yaitu pengerjaannya sederhana, cepat, dan reversible (Goldman et al. 2016).

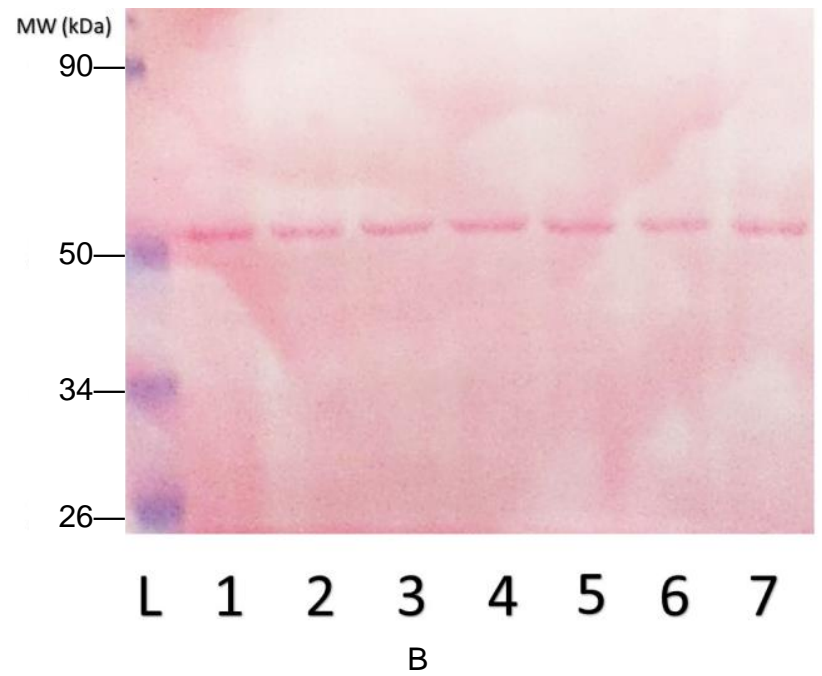

Gambar 4. Hasil pewarnaan Ponceau S. (L: Ladder protein, 1-7: Lisat protein daun tanaman padi) A. Membran untuk blocking menggunakan susu skim 0,2\%, B. Membran untuk blocking menggunakan BSA $0,2 \%$ 


\section{Deteksi protein dengan antibodi}

Membran dicuci menggunakan PBST

$0,1 \%$. Tahap pencucian sangat penting untuk meminimalkan background pada membran dan menghilangkan sisa antibodi yang tidak terikat (Mahmood dan Yang 2012). Selanjutnya, tahap blocking membran menggunakan larutan blocking susu skim $0,2 \%$ atau BSA $0,2 \%$. Menurut Bass et al. (2017), tahap blocking penting untuk mencegah pengikatan antibodi yang tidak spesifik (baik antibodi primer maupun antibodi sekunder) dan mengurangi background pada membran. Idealnya, larutan blocking akan mengikat semua bagian nonspesifik, menghilangkan semua background tanpa mengubah interaksi dengan protein target yang akan terikat dengan antibodi.

Hasil penelitian pada Gambar 5 menunjukkan bahwa penggunaan larutan blocking BSA $0,2 \%$ lebih efektif meminimalkan background pada membran, terlihat dari pita protein yang muncul pada Gambar 5B lebih jelas dibandingkan dengan Gambar 5A. Susu skim banyak digunakan sebagai larutan blocking karena mudah didapat dan harganya relatif murah. Namun, tidak semua label antibodi sekunder kompatibel dengan protein dalam susu, sehingga harus cermat dalam memilih larutan blocking yang tepat. Penelitian Nie et al. (2017) dan Petras et al. (2017), menggunakan susu skim sebagai larutan blocking pada WB untuk deteksi $\beta$-actin, dan didapatkan hasil pita protein dengan high background pada membran yang dapat berpengaruh pada saat perhitungan intensitasnya, sedangkan penelitian WB oleh Vavilis et al (2015) didapatkan hasil pita protein dengan low background pada membran. BSA biasa digunakan untuk label antibodi sekunder biotin dan alkalin fosfatase, dan antibodi antifosfoprotein, karena susu mengandung kasein, yang juga merupakan fosfoprotein dan biotin, sehingga jika

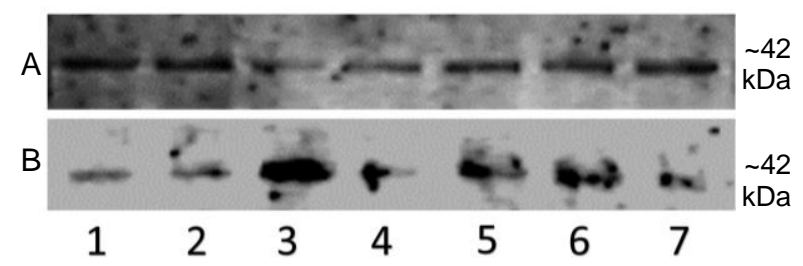

Gambar 5. Hasil WB $\beta$-actin daun tanaman padi: A. Blocking menggunakan susu skim $0,2 \%$, dan B. Blocking menggunakan BSA 0,2\% digunakan akan mengganggu hasil pengujian (Mahmood dan Yang 2012).

Selanjutnya, membran diinkubasi menggunakan antibodi primer $\beta$-actin dengan konsentrasi $1 \mu \mathrm{g} \mathrm{mL}^{-1}$. Penentuan konsentrasi antibodi disesuaikan dengan instruksi dari produsen antibodi. Antibodi $\beta$ actin dilarutkan dalam BSA karena memungkinkan antibodi untuk digunakan kembali, jika membran tidak memberikan hasil yang baik (Mahmood dan Yang 2012).

Pemilihan $\beta$-actin sebagai marker untuk WB didasarkan pada karakteristik protein yang selalu terekspresi dengan baik pada berbagai sel (Li dan Shen 2013, Ghosh et al. 2014, Taylor dan Posch 2014). $\beta$-actin merupakan protein yang terdapat pada sel eukariotik dalam jumlah yang melimpah, umumnya digunakan sebagai kontrol internal untuk menormalisasi dalam studi ekspresi gen ataupun protein (Gorr dan Vogel 2015). Penggunaan kontrol internal dalam biologi molekuler tergantung pada asumsi bahwa tingkat ekspresinya tetap dan konstan antara kontrol dan sampel percobaan dengan ditunjukkan tidak terpengaruh perlakuan atau intervensi dalam setiap kondisi eksperimen (Bass et al. 2017).

Prinsip WB adalah deteksi protein melalui pengikatan dan pengenalan antibodi ke satu atau lebih target. Ikatan ini harus sangat spesifik antara sebagian antigen (protein) atau epitop dan daerah pengenalan khusus yang ditemukan pada fragmen pengikatan antigen yang disebut paratop.

Setelah itu, membran diinkubasi menggunakan antibodi sekunder label horseradish peroxidase (HRP) dengan konsentrasi 1:10.000. Pemilihan antibodi sekunder berdasarkan isotype antibodi primer. Penentuan konsentrasi antibodi disesuaikan dengan instruksi dari produsen antibodi. Label antibodi HRP banyak digunakan dengan mekanisme kerja mengkatalisis oksidasi luminol peroksida untuk menghasilkan asam 3-aminoftalat, menghasilkan cahaya pada $425 \mathrm{~nm}$.

Deteksi pita protein $\beta$-actin dilakukan dengan alat C-Digit LICOR menggunakan substrat chemiluminescence. Prinsip deteksinya berdasarkan cahaya yang dihasilkan dari asam 3-aminoftalat akibat reaksi enzim (HRP)-substrat, yang akan ditangkap dengan film X-ray, kamera ChargeCoupled Device (CCD) atau imager lainnya 
menghasilkan pita protein yang intensitasnya dapat dihitung dengan menggunakan software digital densitometri (Luo et al. 2011, Bass et al. 2017).

Hasil WB pada Gambar 5 menunjukkan bahwa antibodi yang digunakan spesifik dan cukup sensitif untuk mendeteksi protein target. Namun, masih diperlukan optimasi lebih lanjut untuk konsentrasi BSA yang digunakan karena pita protein yang dihasilkan belum konsisten.

\section{KESIMPULAN}

Optimasi kondisi WB dengan mengatur formulasi larutan blocking menggunakan BSA $0,2 \%$, dan konsentrasi antibodi primer $1 \mu \mathrm{g}$ $\mathrm{mL}^{-1}$ khususnya $\beta$-actin dan antibodi sekunder yang bersesuaian dengan konsentrasi 1:10.000 akan memberikan gambaran pita protein yang lebih jelas dan baik.

\section{UCAPAN TERIMA KASIH}

Penelitian ini didanai oleh Hibah Internal Unpad dalam skema Hibah Riset Tenaga Kependidikan Universitas Padjadjaran Gelombang I Tahun 2018 kepada Susianti.

\section{DAFTAR PUSTAKA}

Alegria-Schaffer A, Lodge A, Vattern K (2009) Performing and optimizing western blots with an emphasis on chemiluminescent detection. Methods Enzymol 463:573-599. doi: 10.1016S0076-6879(09)63033-0

Ariyarathna $\mathrm{HA}$, Oldach $\mathrm{KH}$, Francki MG (2016) A comparative gene analysis with rice identified orthologous group II HKT genes and their association with $\mathrm{Na}^{+}$concentration in bread wheat. BMC Plant Biol 16:21. doi: 10.1186/s12870016-0714-7

Bass JJ, Wilkinson DJ, Rankin D, Phillips BE, Szewczyk NJ, Smith K, Atherton PJ (2017) An overview of technical considerations for western blotting applications to physiological research. Scand J Med Sci Sports 27:4-25. doi: 10.1111/sms.12702

Chatterjee M, Gupta S, Bhar A, Das S (2012) Optimization of an efficient protein extraction protocol compatible with twodimensional electrophoresis and mass spectrometry from recalcitrant phenolic rich roots of chickpea (Cicer arietinum L.) Int J Proteomics 2012:1-10. doi: $10.1155 / 2012 / 536963$

Cima-Cabal MD, Vazquez F, de Los Toyos JR, Del Mar García-Suárez M (2019) Protein expression analysis by western blot and protein-protein interactions. Methods Mol Biol 1968:101-111. doi: 10.1007/978-14939-9199-0 9

Esa NM, Ling $\overline{T B}$, Peng LS (2013) Byproducts of rice processing: An overview of health benefits and applications. J Rice Res 1:107. doi: $10.4172 /$ jrr. 1000107

Esteves CV, de Campos WG, de Souza MM, Lourenço SV, Siqueira WL, LemosJúnior CA (2019) Diagnostic potential of saliva proteome analysis: A review and guide to clinical practice. Braz Oral Res 33:1-13. doi:10.1590/18073107bor-2019.vol33.0043

Feckova $B$, Kimáková $P$, Ilkovičová $L$, Szentpéteriová E, Debeljak N, Solárová Z, Sačková V, Šemeláková M, Bhide M, Solár P (2016) Far-western blotting as a solution to the non-specificity of the anti-erythropoietin receptor antibody. Oncol Lett 12:15751580. doi:10.3892/ol.2016.4782

Ghosh R, Gilda JE, Gomes AV (2014) The necessity of and strategies for improving confidence in the accuracy of western blots. Expert Rev Proteomics 11:549-560. $10.1586 / 14789450.2014 .939635$

Gibbons J (2014) Western blot: Protein transfer overview. North Am J Med Sci 6:158-159. doi:10.4103/19472714.128481

Gilda JE, Gomes AV (2013) Stain-free total protein staining is a superior loading control to $\beta$-actin for western blots. Anal Biochem 440:186-188. doi: 10.1016/j.ab.2013.05.027

Goldman A, Harper S, Speicher DW (2016) Detection of proteins on blot membranes. Curr Protoc Protein Sci 86:1-11. doi: 10.1002/cpps.15

Gorr TA, Vogel J (2015) Western blotting revisited: Critical perusal of underappreciated technical issues. 
Proteomics Clin Appl 9:396-405. doi: 10.1002/prca.201400118

Gulcicek EE, Colangelo CM, McMurray W, Stone K, Williams K, Wu T, Zhao H, Spratt H, Kurosky A, Wu B (2005) Proteomics and the analysis of proteomic data: An overview of current protein-profiling technologies. Curr Protoc Bioinformatics 13:1-40. doi: 10.1002/ 0471250953. bi1301s10

Huang YT, van der Hoorn D, Ledahawsky LM, Motyl AAL, Jordan CY, Gillingwater TH, Groen EJN (2019) Robust comparison of protein levels across tissues and throughout development using standardized quantitative western blotting. $\mathrm{J} \quad$ Vis $\operatorname{Exp}$ 146:e59438. doi:10.3791/59438

Kurien BT, Scofield RH (2015) Western blotting: Methods and protocols. Methods in Molecular Biology Vol 1312. Springer Science-Business Media, New York

Lesmana R, Hanna G (2017) Fisiologi molekuler seri prosedur dan protokol laboratorium western blot. Fakultas Kedokteran Universitas Padjadjaran, Jatinangor

Li Q, Liu H, Du D, Yu Y, Ma C, Jiao F, Yao H, Lu C, Zhang W (2015) Identification of novel laminin- and fibronectin-binding proteins by far-western blot: Capturing the adhesins of Streptococcus suis type 2. Front Cell Infect Microbiol 5:82. doi: 10.3389/fcimb.2015.00082

Li R, Shen Y (2013) An old method facing a new challenge: Re-visiting housekeeping proteins as internal reference control for neuroscience research. Life Sci 92:747-751. doi: 10.1016/j.Ifs.2013.02.014

Li X, Bai H, Wang X, Li L, Cao Y, Wei J, Liu Y, Liu L, Gong X, Wu L, Liu S, Liu G (2011) Identification and validation of rice reference proteins for western blotting. J Exp Bot 62:4763-4772. doi: 10.1093/jxb/err084

Lin D-G, Wang C-S (2014) Extraction of total proteins from rice plant. Bio-protocol 4:e1277. doi: 10.21769/BioProtoc. 1277

Luo H, Rankin GO, Straley S, Chen YC (2011) Prolonged incubation and stacked film exposure improve sensitivity in western blotting. $J$ Pharmacol Toxicol Methods 64:233237. doi: 10.1016/j.vascn.2011.06.001
Mahmood T, Yang P-C (2012) Western blot: Technique, theory, and trouble shooting. North Am J Med Sci 4:429434. doi: 10.4103/1947-2714.100998

Mishra M, Tiwari S, Gomes AV (2017) Protein purification and analysis: Next generation western blotting techniques. Expert Rev Proteomics 14:1037-1053. doi: 10.1080/14789450.2017.1388167

Nie X, Li C, Hu S, Xue F, Kang YJ, Zhang W (2017) An appropriate loading control for western blot analysis in animal models of myocardial ischemic infarction. Biochem Biophys Rep 12:108-113. doi: 10.1016/j.bbrep.2017.09.001

Niu L, Yuan H, Gong F, Wu X, Wang W (2018) Protein extraction methods shape much of the extracted proteomes. Front Plant Sci 9:802. doi: 10.3389/fpls.2018.00802

Petras M, Drgova A, Kovalska M, Tatarkova Z, Tothova B, Krizanova O, Lehotsky J (2017) Effect of hyperhomocysteinemia on redox balance and redox defence enzymes in ischemia-reperfusion injury and/or after ischemic preconditioning in rats. Cell Mol Neurobiol 37:1417-1431. doi: 10.1007/s10571-017-0473-5

Rodrigues EP, Torres AR, da Silva Batista JS, Huergo L, Hungria M (2012) A simple, economical and reproducible protein extraction protocol for proteomics studies of soybean roots. Genet Mol Biol 35:348-352. doi: 10.1590/S141547572012000200016

Schurer JM, Nishimwe A, Hakizimana D, Li H, Huang Y, Musabyimana JP, Tuyishime E, MacDonald LE (2019) A one health systematic review of diagnostic tools for Echinococcus multilocularis surveillance: Towards equity in global detection. Food Waterborne Parasitol 15:1-24. doi:10.1016/j.fawpar.2019.e00048

Taylor SC, Posch A (2014) The design of a quantitative western blot experiment. BioMed Res Int 2014:361590. doi: $10.1155 / 2014 / 361590$

Vavilis T, Delivanoglou N, Aggelidou E, Stamoula E, Mellidis K, Kaidoglou A, Cheva A, Pourzitaki C, Chatzimeletiou K, Lazou A, Albani M, Kritis A (2015) Oxygen-glucose deprivation (OGD) modulates the unfolded protein response (UPR) and inflicts autophagy in a PC12 hypoxia cell line model. Cell 
Mol Neurobiol 36:701-712. doi: 10.1007/s10571-015-0250-2

Vilhena MB, Franco MR, Schmidt D, Carvalho G, Azevedo RA (2015) Evaluation of protein extraction methods for enhanced proteomic analysis of tomato leaves and roots. An Acad Bras Cienc 87:1853-1863. doi: 10.1590/00013765201520150116

Villafanez F, Gottifredi V, Soria G (2019) Development and optimization of a miniaturized western blot-based screening platform to identify regulators of post-translational modifications. High Throughput 8:E15. doi:10.3390/ht8020015

Walentowicz-Sadlecka M, Dziobek K, Grabiec M, Sadlecki P, Walentowicz P, Mak P, Szymankiewicz M, Kwinta P, Dutsch-Wicherek M (2018) The analysis of human leukocyte antigen-G level in patients with endometrial cancer by western blot technique. Am J Reprod Immunol 81:1-10. doi:10.1111/aji.13070

Wang W, Tai F, Chen S (2008) Optimizing protein extraction from plant tissues for enhanced proteomics analysis. J Sep
Sci 31:2032-2039. doi: 10.1002/jssc.200800087

Wu J, Lee DY, Wang Y, Kim ST, Baek S-B, Kim SG, Kang KY (2014) Protein profiles secreted from phylloplane of rice leaves free from cytosolic proteins: Application to study rice-Magnaporthe Oryzae interactions. Physiol Mol Plant Pathol 88:28-35. doi: 10.1016/j.pmpp.2014. 08.003

Zhang $\mathrm{C}$, Li H, Wang J, Zhang B, Wang W, Lin H, Luan S, Gao J, Lan W (2017a) The rice high-affinity $\mathrm{K}+$ transporter OsHKT2;4 mediates $\mathrm{Mg}^{2+}$ homeostasis under high-Mg2+ conditions in transgenic Arabidopsis. Front Plant Sci 8:1823. doi: 10.3389/fpls.2017.01823

Zhang Y, Tang L, Liu X, Liu L, Cao W, Zhu Y (2017b) Modeling the leaf angle dynamics in rice plant. PLoS One 12:e0171890. doi: 10.1371/journal.pone.0171890

Zhao L, Liu C, Sun Y, Ban L (2012) A rapid and simplified method for protein silver staining in polyacrylamide gels. Electrophoresis 33:2143-2144. doi: 10.1002/elps.201200107 